\title{
Elementary school students' perceptions of libraries and librarians.
}

\author{
Elizabeth A. Lee \\ Associate Professor \\ Queen's University \\ Canada
}

Don A. Klinger

Associate Professor

Queen's University

Canada

\begin{abstract}
Elementary school students in Grades 3 to 8 in eight schools that had exemplary library programs were surveyed about their perceptions of the school library program and the teacher librarian. Students reported that the teacher librarian was knowledgeable and helpful and taught them key information literacy concepts. The library program supported them in reading for pleasure. The physical space of the library was significant to them and they perceived the library as a welcoming place used for multiple activities.
\end{abstract}

Elementary students, exemplary libraries, teacher librarians

School libraries are intended to support students across multiple learning outcomes; fostering a love of reading, teaching information literacy skills, and encouraging knowledge acquisition across subject areas. What do elementary school students' value about the library and what is their understanding of the teacher librarian's role? How do they think school libraries could be improved?

The attitude and perceptions of library patrons has been a reoccurring concern in the library field at all levels (Gallo 1995; Buckingham 2002; Hayter, 1998). This has come to be know as library anxiety and has been attributed to a various causes (Mellon, 1986). Research has been carried out in public libraries, academic libraries and school libraries. These studies suggest that many users have an overall negative perception of the library as an institution. Frequently individuals had a limited view of the library as a repository for books and hold a stereotypic view of the librarian as being preoccupied with silence and as out of touch with the modern world (Myer, 1999).

Research with a school-aged population has been mostly carried out with adolescents. An early study by Burke (1993) investigated students' perceptions and use of the school library. It was found that students' perceptions were linked to classroom instruction. Recently Rafste (2005) examined how Norwegian high school students' used and valued the school library. She found that only a small number of the high school students used the library on a regular basis and these students valued it as a social space. There was little use of it for 
information retrieval purposes on the part of any students. Shenton (2007) investigated the perceptions that high school students in north-east England had of the school library. These students indicated that they believed the main purpose of the library was to support their academic learning, although overall use of the library was limited. The students held the view that the library was an uncomfortable space with too many restrictions.

A study that included younger students in their sample was the Ohio study of Todd, Kuhlthau, and OELMA (2004). Elementary school students were investigated along with high school students. The questions addressed these students' perceptions of the school library in relation to the help that it offered. Students identified the school library as an important support for their learning and the teacher librarian as one who provided expertise and help with a variety of informational needs. This research was a welcome addition to the field by eliciting student voices for how the library supported academic achievement. It compliments the research on the role of libraries and librarians in supporting students' academic growth. A substantial body of research links the positive impact of school libraries and school librarians to students' test scores in the United States. Students in schools with well-staffed, -stocked and -funded libraries score from $10 \%$ to $25 \%$ higher on standardised tests than students in schools with poorly resourced libraries (Baughman, 2000; Baumbach, 2002; Burgin and Brown-Bracy, 2003; Lance, Rodney, and Hamilton-Pennel, 2000a, 2000b, 2002). International studies have linked student achievement and the presence of professionally staffed and accessible school libraries (OECD, PISA,2001).

The most extensive study of elementary students' perceptions of the role of the librarian was carried out by Mellon (1995). She interviewed 44 grade 6 students from a range of academic achievement levels about what they liked and didn't like about their school libraries. Mellon stated that the students' perceptions varied due to individual differences among the librarians. She found that these students overall had a positive perception of the librarian as someone who was nice and helpful. The librarian was characterized as nice when she was helpful. This was linked to making resources for classroom assignments available to the students. Students generalized the attitude developed in response to their specific school librarian to libraries and librarians as a whole. De Guzman, Custodio \& Garcia (2007) investigated Filipino grade school students' perceptions of school librarians through the medium of doodles. These Grades 4 to 6 students' doodles revealed two images; a desirable librarian who was sociable and helpful and an undesirable librarian who unavailable and unresponsive to students. A small study in one Canadian elementary school investigated Grade 3 students' understanding of a library through asking them what word they associated with the word library. These students held a traditional view of the library as being a place for books (Nesset \& Shenton, 2007). The majority of these studies paint a rather bleak picture of students' perceptions of libraries and librarians.

The oldest tradition in the library field has been a concern for children's reading behaviour and the role that the library and librarian play in fostering children's reading engagement. Research in the psychology of reading has established that the amount of reading that a child does is correlated with their reading achievement (Anderson, Wilson \& Fielding, 1988). Krashen (2006) has extended this work to examining the role that the library can play in reading achievement, especially through encouraging summer reading. 
This study was part of a larger study that examined exemplary school libraries. What were the students' perceptions of the teacher librarian's role? What were their experiences with the teacher librarian? What were their views of the library program?

\section{Methodology}

The research study was conducted in nine schools located in southern Ontario that were identified by the Ontario Library Association (OLA) as having exemplary school library programs. The school were from three public and one catholic school board, representing a large city, a mid sized city and suburban and semi rural regions. Data for the current study were obtained from student surveys distributed to three to four classes in each school. A total of 331 (41\% return rate) student surveys returned from eight of the schools (the student data from one school were lost in transit). To minimize the impact on the classroom teacher, the surveys were sent home with the students to complete. The lowest return rate was $17 \%$ (13 of 75 returned) and the highest was 66\% (76 of 115 returned).

The student surveys included 6 open-ended and 27 Likert scale survey items enabling qualitative and quantitative analyses to be conducted. The open-ended questions focused on important features of the library as perceived by students (e.g., "The single best thing about our school library is.... If I could, the one thing I'd do to improve out school library would be...”). The Likert items examined frequency of activities (I go to the school library at lunch time), and perceptions of the librarian's role (The librarian helps me choose books). These items were contained within five major sections: (a) student demographics and school attitudes; (b) library activities during class time and during students' own time; (c) items used in the library and factors that help students choose books; (d) librarian characteristics and perceptions of the librarian; and (e) students' reading attitudes and perceptions of reading. Descriptive and inferential statistics of the quantitative survey data were analysed using SPSS 16.0. Excel was used to classify the qualitative data into themes.

The students who completed the surveys were in Grades 3 to 8, with the majority being in Grades 4 to 6 (ages 8 to 12 years). The average age of the students was 10.4 years of age. A higher proportion of girls completed the survey (57\%). Just under three-quarters of the students were born in Canada but only 50\% listed English as their first language, with Chinese (including Mandarin and Cantonese) being the most commonly reported other language. Thus the sample generally represents the diversity of the student population found in these schools, although thee were slightly more girls and fewer immigrant students than found in the actual student population.

\section{Results}

Findings from the quantitative analysis are reported first. Factor analysis did not result in simple structure. Hence we examined the data at the item level. Following these results findings from the open-ended questions are reported. 


\section{The Students’ Perspectives}

\section{Perceptions of the teacher-librarian}

Based on out results these students appreciated the exemplary library programs present in their school and the services provided by the school librarian. Figure 1 contains the results from nine survey items examining students' perceptions of the teacher-librarian. The proportions of students who agreed or strongly agreed with each statement are reported in Figure 1, representing positive perceptions for each attribute.

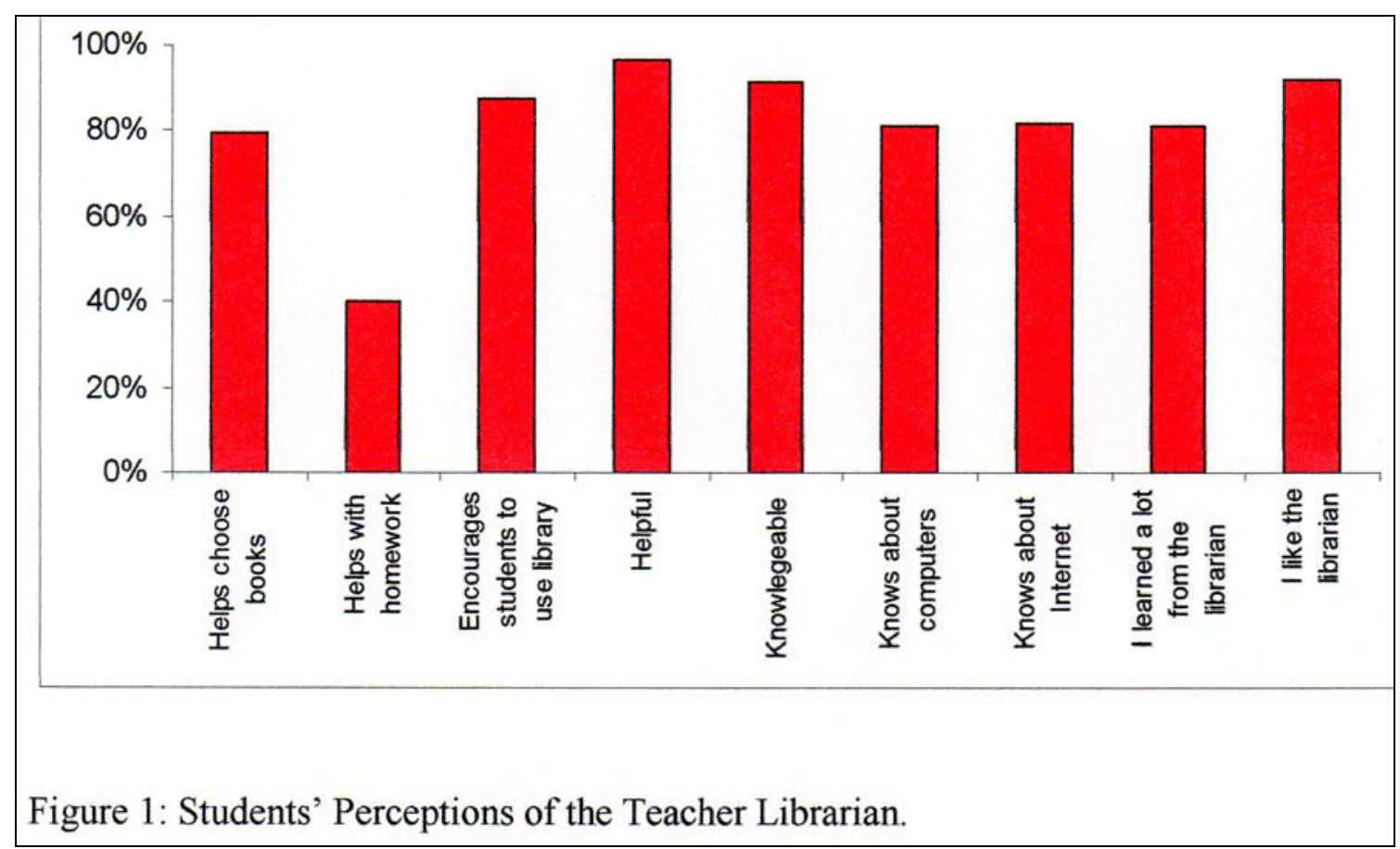

The students were very positive about the school librarian with (91\%) stating they liked the librarian (agree or strongly agree). Overall, 83\% of the students believe they learned a lot from the librarian, and $93 \%$ of the students believed their teacher-librarian to be knowledgeable and helpful. In contrast it is not surprisingly that students infrequently turned to the school librarian for help with homework (41\%). Interestingly, there was large variability across the schools with respect to students' perception of the teacher librarians' expertise and skills, especially in terms of computer and the Internet expertise. This is understandable given that these school libraries differed in terms of computer access.

Perceptions of teacher-librarian's responsibilities.

Figure 2 illustrates students' views of the roles and responsibilities of the teacherlibrarian. Students responded to these items with a "Yes" or "No" response, the figure contains the proportion of students responding "Yes" to the specific item. 


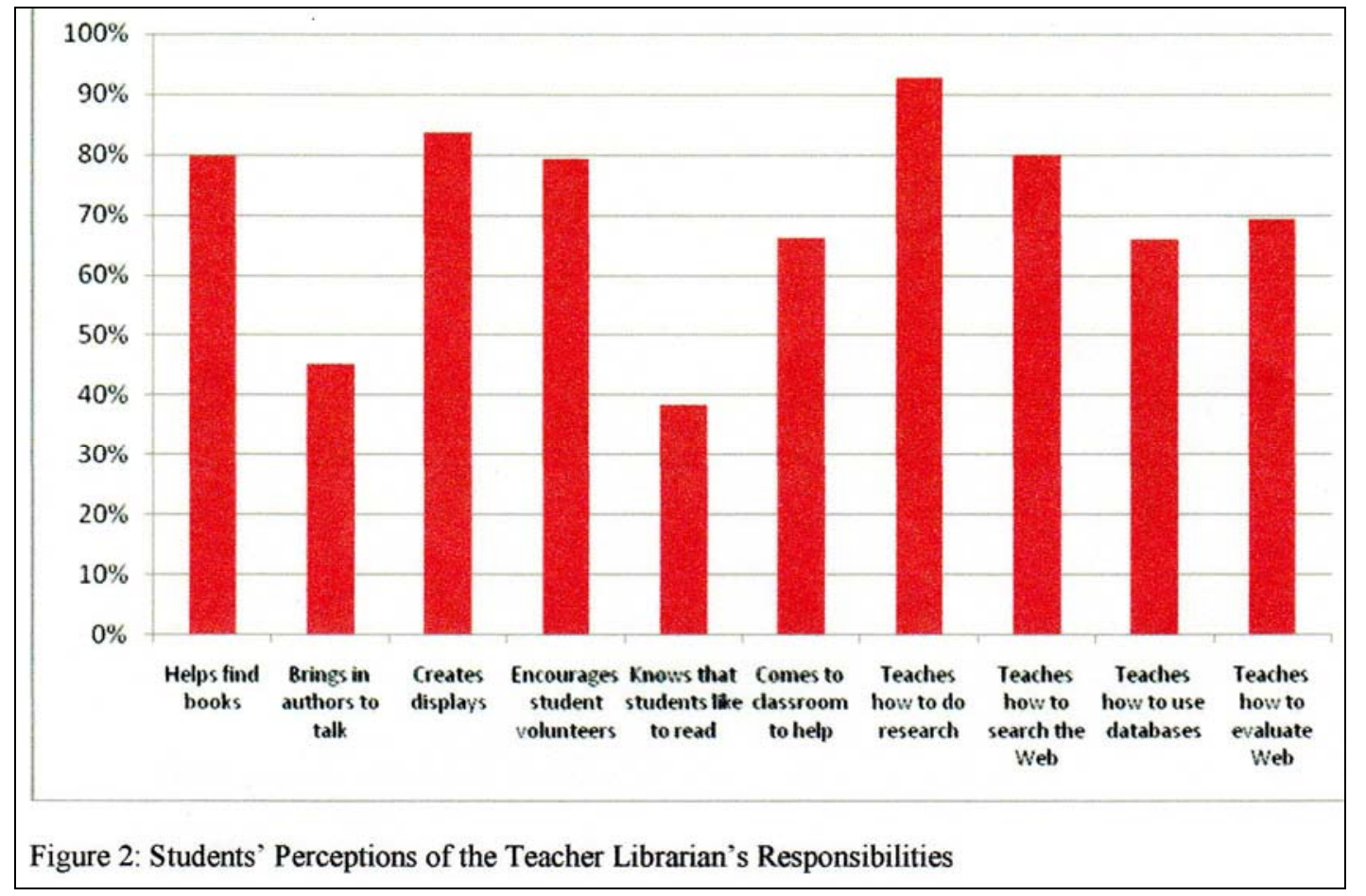

Students indicated that these exemplary teacher-librarians taught them multiple aspects of information literacy. Students ranked teaching students how to do research as the highest response at 92\%, followed closely by other core aspects of information literacy, searching the web (80\%) and how to use databases (65\%) among other visible responsibilities. Interestingly, $66 \%$ of the students reported that these teacher-librarians came to their classrooms. In contrast, a surprisingly low number of students (38\%) generally believed that the teacher-librarian knew the kinds of books they like to read. This may be due to the transient nature of students' book choices, typically reflecting the most currently popular titles and formats (graphic novels). These books often take time to arrive in the school. The student responses to the open-ended questions provide further insight into the reasons for this result.

\section{Variations in perceptions.}

The students' perceptions of the library were as varied as the programs we observed. When we initiated this study, it was our intention to use student surveys to examine the consistency of exemplary school library programs in terms of the services provided to students. However, on analysis it became clear that the context within which a school library operated had a substantial role in setting the parameters for the program. Our analysis shifted to examining the range of uses found amongst exemplary programs through the eight case studies. The students were consistent in speaking highly of the school library, but the reasons for their views varied.

For example, the increasing demand for instructional technology has resulted in some schools incorporating the computer lab into the school library. These school library programs now include elements of instructional technology. The teacher librarian is expected to manage and incorporate this technology into his or her library program, and students in these schools commonly use the library for this purpose. However, in other schools the 
instructional technology program is separate from the school library program. Hence, the school context plays an important role in understanding the students' perceptions of the teacher librarian and more importantly, the role of the school library. The Profile Graph in Figure 3 highlights this variability in school library programs.

Figure 3 contains the same results that were provided in Figure 1 but separating the average proportions for each school. Using the data from students who reported they used the library at least a couple of times the proportions of students across the schools are shown in Figure 3. The following information is provided for each item:

- The line shows the range between the highest and lowest average proportions from each of the schools surveyed.

- The cross hair shows the weighted average from all schools surveyed.

In this manner each school is given equal weight in the calculations, regardless of the number of students surveyed in each school.

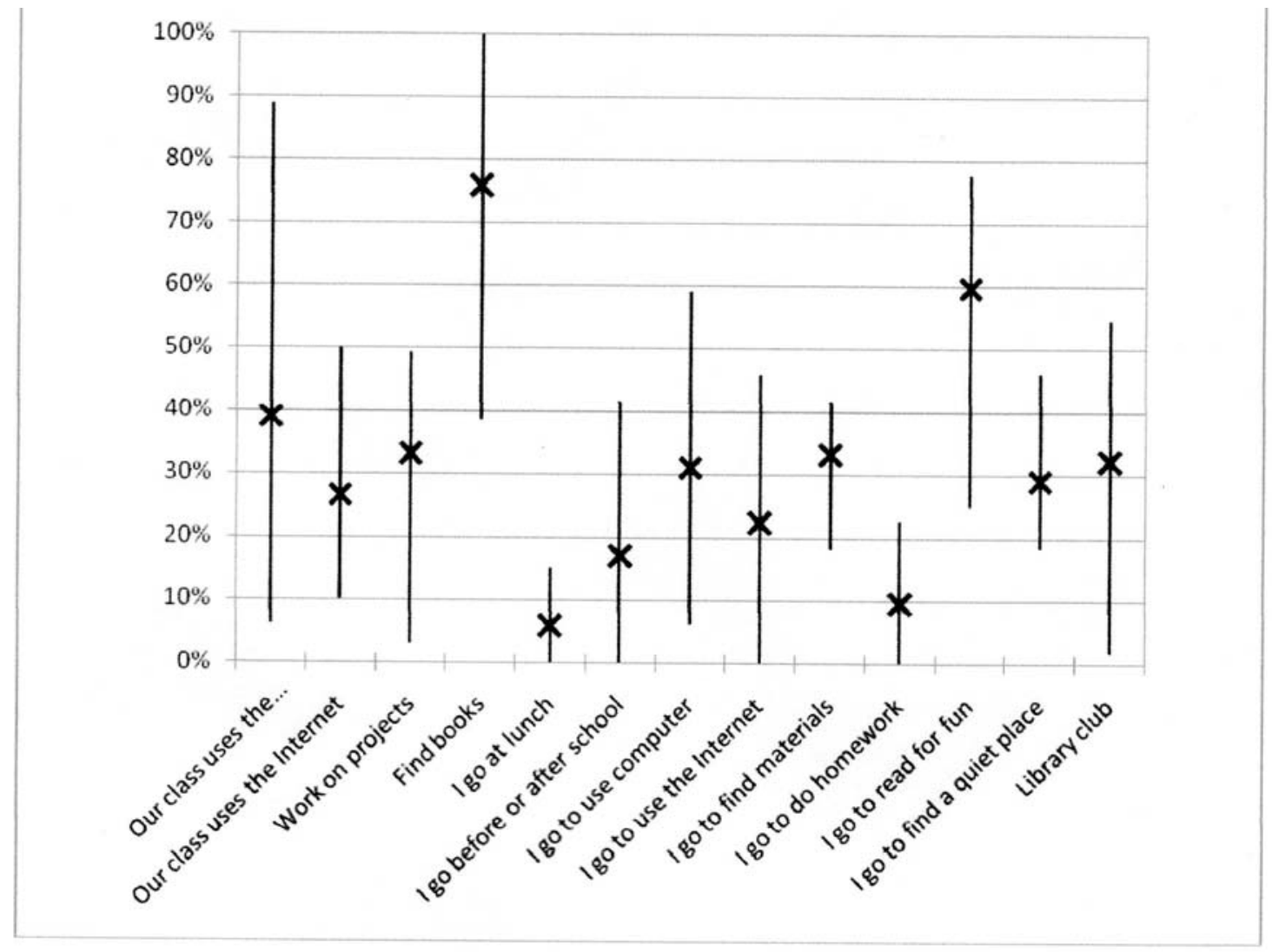

Figure 3: School Variability in Students' Perceptions of the Teacher Librarian.

As seen, students overwhelmingly (97\%) perceived that the librarian was helpful with little variability amongst the schools. Similarly, the students in each of the schools reported they liked the school librarian. The greatest variation amongst the students' perceptions was for how knowledgeable the librarian was about computers ranging from $48 \%$ to $100 \%$ of the 
students in a school agreeing or strongly agreeing with the statement that the teacher librarian was knowledgeable about computers. Across the schools, $82 \%$ of the students agreed with this statement. There was similar variability in students' perceptions regarding their teacher librarian's knowledge of the Internet ranging from 52\% to $100 \%$. Again, these results are most likely due to differences across the schools in terms of how instructional technology is accessed and used in the schools. In contrast there was little variability across the schools in terms of students' perceptions that the teacher librarian helped them select books ranging from $68 \%$ to $90 \%$. What may be of more surprise is that these values were not $100 \%$, suggesting that these librarians certainly have other responsibilities beyond traditionally perceive roles.

\section{Student use of library}

The qualitative data added insight into the students' uses and attitudes. The first openended question asked the students "Please tell us any other activities you did in the school library this year?" This question elicited the greatest number of responses, 272 students out of 331 provided at least one answer for a response rate of $82 \%$. Some students gave more than one answer for a total of 317 items. The most frequent activity was extracurricular (24\%) with a wide variety of activities mentioned "We practice our dance groups in the library." "Origami workshop" "Visit school pets." "Drama and choir." This was followed in frequency (19\%) by reference the teacher librarian teaching or to doing research projects. "We went to learn about persuasive writing." "We did research about the First Nations." "We did a medieval project with the librarian.” Other activities mentioned were book exchange $(12 \%)$, being a library helper (10\%), participating in a book club (8\%), classes with their teacher (7\%), watching videos, studying, internet use, book fairs and partners teaching.

Students were asked to complete the statement "The single best thing about our school library is..." A total of 190 students (57\%) responded to the item with 10 students providing more than one response. The most frequent response (55\%) referred to the number of books available or to a specific type of book "It has SO MANY BOOKS!" "The amount of books we have and how interesting they are." What was surprising and unexpected was that the next most frequent response to this question (34\%), were statements that referred to the physical space, organization or atmosphere of the library. Students commented, "There is a lot of room to read quietly." "It's extremely quiet, so no one can bother you." "Everything in the library is neat and tidy." "The fact that every type of books are separated in different sections." Many of these young students valued the quiet and order found in their school library, an interesting finding given that the current classroom models increasingly emphasize group work with an associated higher noise level. For a considerable number of students $(12 \%)$ the librarian was the best thing about their library, "We have a great librarian that is

smart, nice and is always a happy person!" "How it is always abuzz it always helpful and welcoming with a teacher/librarian that makes us feel right at home.” The remaining 15\% largely referred to specific aspects of particular libraries, for example, the pets found in one library, watching videos, and reading clubs.

\section{How to improve}

Students were also asked the following questions: "If I could, the one thing I would do to improve our school library would be to...” A total of 185 students (56\%) responded with 19 students giving more than one response, resulting in a total of 204 items. The most 
common response was a desire for more books (46\%), often specifying a particular type. "Finish all the unfinished series because some of the series are cut off and you have to run to the public library." "Get more NEW books." "More graphic novels.” This was followed in frequency by responses that referred to the physical space (27\%). "Make it bigger and spacier (sic). It's too crowded" or reference to the order in the library "Be more organized with the books." Many of the comments about the physical space referred to having more shelves in order to have room for more books "Add more space for shelves." This response was followed in frequency (7\%) by comments wanting more time in the library or to be allowed to take out a greater number of books "If I could change one thing about the library I would keep library period everyday." Overall students had a positive view of the school library and librarian, but these comments further highlight the variability across school libraries.

\section{Encouraging use}

The fourth open-ended question was "The best way to encourage students to use the library is to..." Out of 331 students 183 responded for a response rate of 55\%. There were 4 students who gave more than one response for a total of 187 items. The most frequent advise (21\%) was to tell the students about the library " Tell them about the wonderful books we have.” Tell them that we've got new books.” This was followed in frequency (20\%) by reference to interesting books "Get a new book everyday." " Have books that students like to read." "GET MORE BOOKS.” The third most popular suggestion was to inform students by advertising (17\%) with posters "Make some posters on non-fiction and graphic novels." or showing students "Show them the cool books in the library." This category was followed in frequency with suggestions to provide activities and clubs (11\%) "Do more activities" "Make it fun (I don't know how to)." Other suggestions were to emphasize learning (8\%) "To do their research." Six percent thought that increasing the amount of access would encourage more use "Have a lot more classroom access to the library" "Bring them to the library everyday."

\section{Reading Behaviour}

The students valued their school libraries with $64 \%$ stating they would like to be able to use the library more frequently. The students generally reported that they liked to read at home and at school (76\% stated it was true or mostly true) and $78 \%$ thought they were "great" readers. Ninety-four percent of the students had read a book for pleasure in the past month and 83\% reported they had used books to help with their schoolwork. Generally, students reported reading between 1 and 12 books for pleasure (median $=5$ ) and using 1 to 10 books (median $=3$ ) to help with schoolwork. Students were asked to indicate from a list of 15 activities "Which of these activities do you think help encourage students to read?" A total of 329 students completed this section (see table 1).

\begin{tabular}{|l|c|l|c|}
\hline \multicolumn{1}{|c|}{ Activity } & Percentage & \multicolumn{1}{c|}{ Activity } & Percentage \\
\hline Reading groups or literature circles & 54 & Talking about favourite books & 68 \\
\hline Reading games & 65 & Choosing books for the library & 67 \\
\hline Writing stories & 55 & Playing games on the computer & 37 \\
\hline Writing book reviews & 39 & Helping younger children read & 67 \\
\hline Designing displays for the library & 57 & Reading for charity/sponsorship & 57 \\
\hline Designing website/magazines & 49 & Rating books for friends & 57 \\
\hline Reading for a competition or prizes & 68 & Meeting authors & 86 \\
\hline
\end{tabular}


Table 1. Percentage of students indicating an activity would encouraging reading.

The majority of the activities had over $50 \%$ of the students indicating that they thought it would encourage reading. Meeting authors was chosen by the greatest number of students while writing book reviews, not unexpectedly, was not a popular choice.

\section{Reading choices}

The fifth open-ended question asked the students to name their favourite book. There were a total of 317 responses from the 331 students for a response rate of $96 \%$. The titles were categorized into type of book with fiction being the most popular (61\%) form. This was followed in frequency (20\%) by graphic novels, comics and humour books. Non-fiction books were listed by $11 \%$ of the students, while $3 \%$ stated that there were too many to choose one. Not surprisingly, in the fiction category Harry Potter was the most frequent title. Other than Harry Potter no other title was provided more than 4 times. Among the graphic novels Bone was the most frequent title, listed 6 times. The other titles ranged from manga, superheroes, and cartoons. Topics in the non-fiction books ranged from biography (Helen Keller), science (Rocks and Minerals) to history (WWII) with little overlap. The last openended item that asked students to complete the sentence "The kinds of things that I like to read include:" There were 310 students who responded out of 331 for a 95\% response rate. Students responded by naming types of books -fiction, non-fiction, novels, series, chapter books, magazines and graphic novels as well as giving topics, ranging from fantasy, adventure, scary, mystery to sports. The most frequently type of book was fiction while most frequently mentioned topics were adventure and humour.

\section{Discussion}

In this study students' perceptions of school libraries and teacher librarians are overwhelmingly positive. This in part may be due the younger age of these participants, unlike most of the earlier studies that surveyed adolescents. Attitudes toward various aspect of schooling declines overall the longer students are in school. As the study was carried out in school libraries that had been identified as exemplary by leaders in the field this may have contributed to the positive perspective of the students. They rated the libraries and teacher librarians highly because they truly were exceptional. However, although nominated as exemplary, the school library programs fell along a continuum. There were libraries that had only part time librarians with limited budgets who were mostly responsible for prep coverage with little time for working with students. Other libraries had a fulltime teacher librarian who had additional funding and who was able to teach and collaborate extensively with classroom teachers. As shown in the results students across schools had positive perceptions about most aspects of the library and librarian. In these school libraries the majority of the students had an opportunity to learn key information literacy skills and strategies from the librarian. Perceptions that differed across schools reflected the specific contexts of the school especially how computers were utilized in the school.

Another factor contributing to the positive perceptions could be how the questions were framed. We asked questions that were positive in nature: "What is the best thing... Your favourite book... Improve the library..." as opposed to "What would you like changed 
about the library?” These subtle differences in wording may prompt a respondent to frame her response in a negative or a positive way.

An unexpected finding was how physical space and the arrangement of it are important. The aesthetics of the space mattered to students; tidiness, commenting upon whether books were shelved, the bulletin board displays, how books were featured. The library was seen as a haven, we were surprised at the number of students who appreciated the library as a quiet place, where they could read in peace. Students noticed the physical layout, and disliked being crowded. They noted if the library was well organized, shelves labelled and specific sections for different activities. A common comment about how to improve the library was a suggestion for more shelving to allow for more books. While not asked directly about the collection, students frequently stated that their library had many books on a wide variety of topics; nevertheless, they believed that there needed to be more books available in their library.

These schools libraries were busy places, with the majority of the students using it for at least one extracurricular activity in addition to obtaining books for pleasure reading and information literacy instruction. The majority of the students enjoyed reading and had specific opinions about the type of books they liked to read. This was the source of the belief of many of the students that the librarian didn't know what type of books students liked. Whether it was graphic novels, mysteries or serial books since there was a limited number of each type this was interpreted by the students as the librarian not knowing what students liked because if librarians knew there would unlimited books of the type they preferred.

Similar to the perceptions of teacher librarians reported by Todd and Kuhlthau these students had a positive view of teacher librarians and the library. They reported being taught information literacy skills by the librarian, participating in reading clubs and using it as a source of books for pleasure reading. These teacher librarians were successful in providing an enriching and engaging program to elementary students.

\section{References}

Anderson, R. C., Wilson, P. T., \& Fielding, L. G. (1988). Growth in reading and how children spend their time outside of school. Reading Research Quarterly, 23, 285-303.

Baughman, J. (2000). School libraries and MCAS scores. Downloaded from http://web.simmons.edu/ baughman/mcasschoollibraries/Baughman

Baumbach, D. (2002). Making the grade: The status of school library media centers in the Sunshine state and how they contribute to student achievement. Spring TX: Hi Willow Research and Publishing.

Buckingham, R. (2002). Highlighting the importance of reading and literacy in secondary school LRCs: A case study. School Librarian, 50, 10-13.

Burks, F. (1996). Student use of school library media centres in selected high schools in Greater Dallas-Fort Worth, Texas. School Library Media Quarterly, 24, 143-9.

Burgin, R. \& Brown-Bracy, P. (2003). An essential connection: How quality school library media programs improve student achievement in North Carolina. Spring, TX: Hi Willow Research and Publishing. 
De Guzman, A. B. Custodio, S. M. B. \& Garcia, M. A. P. (2007). Surfacing Filipino school children's images of librarians through doodling. Libri, 57, 9-26.

Gallo, D. R. (1985). Ask your librarian! American Libraries, 16, 736-9.

Hayter, S. (1998). 'Once you get to this age, it's dull and boring!': The crisis of public library provision for youth with reference to Durham City. MA dissertation, University of Northumberia at Newcastle.

Krashen, S. (2006). Free reading: Is it the only way to make kids more literate? School Library Journal, 52, 4245.

Lance, K.C., Rodney, M.J., \& Hamilton-Pennell, C. (2000a). Information Empowered: The School Librarian as an Agent of Academic Achievement in Alaska School, Rev. ed. Juneau: Alaska State Library.

Lance, K.C., Rodney, M.J., \& Hamilton-Pennell, C. (2000b) How School Librarians Help Kids Achieve Standards: The Second Colorado Study. Castle Rock, Colo.: Hi Willow Research and Publishing.

Lance, K.C., Rodney, M.J., \& Hamilton-Pennell, C. (2002). How School Libraries Improve Outcomes for Children: The New Mexico Study. Salt Lake City, UT: Hi Willow Research and Publishing,

Maynard, S. and R. McKenna 2005.Mother Goose, Spud Murphy and the Librarian Knights: representations of librarians and their libraries in modern children's fiction. Journal of Librarianship and Information Science, 37, 119-129.

Mellon, C. A. (1995). “She's nice and she helps.” What $6^{\text {th }}$ graders say about school librarians. School Library Journal, 41, 27-29

Mellon, C. (1986). Library anxiety: A grounded theory and its development. College and Research Libraries, 47, 160-5.

Meyer, E. (1999). The coolness factor: Ten libraries listen to youth. American Libraries, 30,42-5.

Nesset, V., \& Shenton, A. K. (2007). Are children’s 'Library’ attitudes behind the times? Some insights from a small-scale Canadian study. New Review of Children’s Literature and Librarianship, 13, 139-160.

OECD PISA Study, 30 (2001). Measuring up: The performance of Canada's youth in reading, mathematics and science. Downloaded from http://www.pisa.gc.ca/pisa/81-590-xpe.pdf.

Rafste, E. T. (2005). A place to learn or a place for leisure? Students' use of the school library in Norway. School Libraries Worldwide, 11, 1 10-16.

Shenton, A. K. (2007). Attitudes to book and school libraries among teenagers in an English high school. New Review of Children's Literature and Librarianship, 13, 31-57 DOI:10.1080/13614540701439891

Todd, R.J., Kuhlthau, C. \& OELMA (2004). Student learning through Ohio school libraries: The Ohio research study. Columbus, OH: Ohio Educational Media Association.

Todd, R. J. \& Kuhlthau, C. C. (2005). Listen to the voices: Ohio students tell their stories of school libraries. Knowledge Quest, 33, 8-13.

\section{Biographical Notes}

Author 1: Elizabeth A. Lee is an Associate Professor in the Faculty of Education at Queen's University. Her research focuses on information literacy, and reading comprehension.

Author 2: Don A. Klinger is an Associate Professor in the Faculty of Education at the Faulty of Education. His research focuses on home and school factors affecting educational outcomes. 


\section{Statement of Originality}

This statement certifies that the paper above is based upon original research undertaken by the author and that the paper was conceived and written by the author(s) alone and has not been published elsewhere. All information and ideas from others are referenced. 